\title{
ISSUE FOCUS
}

\section{Migrant Workers' Rights and Status under International Law: the Asian Experience}

\author{
Patricia R.P. Salvador Daway *
}

The importance and extent of the migration phenomenon, affecting as it does huge numbers of people the world over cannot be overemphasized. Coming from third world countries, poverty-stricken and strangers in foreign lands, migrant workers irrespective of country of origin indeed become vulnerable to oppression and exploitation and all kinds of abuses. The question that needs to be addressed continues to be whether or not the existing ILO Conventions and Recommendations as well as the core international human rights treaties together with the International Convention on Migrant Workers have been adequately implemented in order to effectively address the problems related to the promotion and protection of migrant workers' rights. Given the flood of unabated reports and complaints of abuses and exploitation that migrant workers the world over have to suffer and contend with, the answer is quite obvious. While bilateral and multilateral agreements continue to serve the specific concerns of sending and receiving States pertinent to the protection of the rights of migrant workers, the real need is for a continent-wide forum in Asia which can eventually consolidate all mechanisms and measures that will promote and protect the rights of migrant workers in a truly comprehensive and integrated manner.

\section{Keywords}

Migrant Worker, ILO, IOM, ICMW, AsianSLL, International Human Rights Law, Integrated Comprehensive Regional Approach

* Associate Dean of University of the Philippines College of Law \& concurrently, Supervisor of U.P. Law Center for publication in the Journal of East Asia \& International Law (Focus Issue on Migrant Workers). A.B./LL.B (Philippines). The author may be contacted at: psdaway@yahoo.com /Address: U.P. College of Law Malcolm Hall, Diliman, Quezon City, The Philippines. 


\section{Introduction}

\section{A. Background}

In late 2008, the entire world was jolted from its complacency by the widening financial crisis that has spread to economies integrated into the global market, causing "massive retrenchment and lay-offs of workers and increased unemployment in labor receiving and sending countries alike." 1

Indeed in the Philippines which sends one of the biggest contingents of migrant workers all over the world, banner headlines - 200,000 layoffs feared,2 Hundreds lose jobs $^{3}$ - at the beginning of the year 2009, prognosticated hundreds of layoffs on a daily basis in domestic corporations as an offshoot of the global economic crisis which was precipitated by the Lehman Brothers' debacle sometime in October 2008. The Department of Labor and Employment forecasted that: "[I]f companies continue to shed jobs at the present rate, the government may be looking at 200,000 jobless workers in six months." 4

Optimistic business leaders highlighted the options available to affected workers. Those workers "finding themselves suddenly without employment because of the slowing global economy can turn to the information technology and business process outsourcing sectors where thousands of jobs are on offer" or they "can join the approximately 3,000 Filipinos who fly out of the country every day for countries where apparently the demand for Filipino workers has not abated." 5

The global economic crisis, needless to state, will certainly increase the already phenomenal rate of migration at present time and magnify the problems of migrant workers. UN Secretary-General Ban Ki-Moon said: "[G]iven these developments, it would be naive to think the current crisis will have no effect on the movement of people across borders, and how our publics perceive migration and the migrants in their midst." 6 More than ever today, there should be a sustained concern for the implementation of universal, international standards affording protection to migrant workers.

1 M.A. Villalba, Migration: DevelopmentIssue, presented at the Academic Congress of the University of the Philippines (Feb. 1-5, 2010).

2 PhiliPPINE DAILy InQUIRER ("PDI”), Jan. 27, 2009, at A1, available at http://www.inquirer.net (last visited on Sept. 2, 2010).

PDI, Jan. 24, 2009, at A1.

Labor Chief Forecasts Job Losses, PDI, Jan. 27, 2009, at A1.

IT, BPO Sectors can absorb jobless workers, PDI, Jan. 24, 2009, at A1 \& 6. 


\section{B. The Migration Phenomenon in Asia}

The Overview on Migration in Asia7 reveals that "[o]ver the past three decades, international labour mobility has become an increasingly important feature of the Asian economic landscape," relying on the estimated data on Asian migrant workers abroad of "around 25 million," 8 including both within and beyond the "Asian region," much of which are undocumented and not included in official statistics. Asian migration has truly become "an increasingly intra-regional phenomenon." 9

Many East Asian countries, including Thailand and Singapore, indicate high dependence on foreign labour.10 Asian countries, on the basis of their internal labour migration situation, can be classified as: (1) "mainly emigration" (2) "mainly immigration" and (3) "both significant immigration and emigration." Thus, Bangladesh, Cambodia, China, India, Indonesia, Laos, Myanmar, Nepal, Pakistan, the Philippines, Sri Lanka, Vietnam are categorized as 'mainly emigration.' Brunei, Hong Kong SAR, Japan, Macao SAR, Malaysia, Singapore, Republic of Korea (South Korea), Taiwan Province of China are 'mainly immigration.' Thailand is "both significant immigration and emigration." 11

The two Special Administrative Regions of China--Hong Kong and Macao-- have the highest concentration of international migrants in East Asia (43\% and 56\% of their total population, respectively). ${ }^{12}$ Hong Kong SAR is the major destination in East Asia while Japan follows with two million international migrants. 13 In Southeast Asia, Singapore has the highest number of international migrants with 1.8 million, followed by Malaysia with 1.6 million.14 Many Southeast Asian countries are major sources of migrant labour." 15 The Philippines has the largest number of migrant workers in foreign countries. As of 2006, official figures show that 8.2 million overseas Filipinos are distributed as follows: 3.6 million permanent residents, 3.8 million temporary residents and 875,000 irregular migrants. Indonesia, as of the end of 2006 had two million overseas workers. 16

6 Ban Ki-Moon, U.N. Sec' y Gen., Address at the Second Global Forum on Migration and Development, Manila (Oct. 29, 2008).

7 INTERNational Organization For Migration, World Migration 2008: Managing Labour Mobility in the EVOLVing GLOBAL ECONOMY 439 (2008).

$8 \quad$ Id. at 439.

$9 \quad$ Id.

10 Id. at 440.

11 Id. at 439.

12 Id. at 439-440.

13 Id. at 440.

14 Id. at 443.

15 Id. at 444.

16 Id. 


\section{Impact of Global Financial Crisis on Migration}

Addressing the global economic debacle, the Geneva-based International Organization for Migration ("IOM") which has gone a long way since its establishment in 1951 to become "the leading inter-governmental organization in the field of migration," 17 issued IOM Policy Guidance Note 1 dated on January 12, 2009. In sum, IOM opines that the "global financial crisis is expected to lead to a downturn in the global economy (and perhaps a deeper recession)." It admits, though, that the "depth and extent of the crisis is difficult to predict and the impact of the crisis is likely to vary according to country, geographic region and employment sector." 18

The view is advanced that at such a time, the first to lose their jobs are migrant workers, ${ }^{19}$ for which it cautions against any such policy given that sending migrant workers home "could have potentially disastrous consequences for development," if one considers the scale of remittances and the high unemployment rates in developing countries. While optimistic that "[h]uman mobility makes economies more dynamic and more efficient" and may be "a positive force in alleviating various aspects of the financial crisis," IOM predicts that "countries of origin are likely to experience some influxes of returning migrants, which may result in economic and social instability in poorer countries." In the same vein, it warns against possible increases in irregular migration and human trafficking.

Along this line, IOM urges the formulation of "flexible, coherent and comprehensive migration management policies to maximize the benefits of migration, protect migrants and take their needs into account in measures addressing the crisis." Justifying this outlook within the historical context of the oil crisis of the early 1970s and the 1998 Asian financial crisis wherein migration continued with irregular migration even increasing, it concludes that the Asian financial crisis "also demonstrated that keeping markets open to migrants and migration is important to stimulating a quicker economic recovery." 20

IOM, About IOM, available at http://www.iom.int/jahia/Jahia/about-iom (last visited on Sept. 2, 2010).

18 Dall'Oglio, Address at 47th Session of the Commission for Social Development, United Nations, Agenda SubItem 3(a): Social Integration (Feb. 6, 2009), available at http://www.iom.int/jahia/Jahia/media/all-speeches/cache/ offonce/lang/en?entryId=22247(last visited on Sept. 2, 2010).

19 For details, See Center for Migrant Advocacy ("CMA") \& Friedrich Ebert Stiftung ("FES"), The Philippines: A Global Model on Labour Migration?, June 2009, at 14.

$20 \quad$ Supra note 18. 


\section{The Legal Regime Affording Protection to Migrants}

\section{A. ILO Instruments: The Need to Address the Special Concerns of Migrant Workers}

As early as 1919, the need to address the special concerns of the labour sector was brought to fore with the founding of the International Labour Organization ("ILO"), the agency of the United Nations "devoted to labour issues." 21

\section{The Earliest ILO Instruments}

The earliest instrument which underscored ILO's concern for migrant workers was entitled Reciprocity of Treatment Recommendation ("R2") which was adopted in 1919.22 This was followed by six other Conventions/Recommendations namely, Migration Statistics Recommendation ("R19,"1922),23 Inspection of Emigrants Convention ("C21,"1926),24 Migration (Protection of Females at Sea) Recommendation ("R26,"1926), 25 Migration for Employment Recommendation ("R61," 1939),26 Migration for Employment (Cooperation between States) Recommendation ("R62,"1939), 27 and Migration for Employment Convention ("C66,"1939).28 These Conventions/ Recommendations were subsequently, either withdrawn or replaced.

\section{Up-To-Date ILO Instruments}

a. C97 (1949): Migration for Employment Convention

It took the ILO all of three decades to adopt a Convention which sets forth international standards specific to the protection of migrant workers as a special group. This is

21 R. Cholewinski, Protecting Migrant Workers in a Globalized World, at 2 (2005), available at http://www.migrationinformation.org/Feature/display.cfm?id=293 (last visited on Sept. 3, 2010).

22 ILO, Reciprocity of Treatment Recommendation (1919), available at http://www.ilo.org/ilolex/cgi-lex/convde.pl?R002 (last visited on Sept. 2, 2010).

23 ILO, Migration Statistics Recommendation (1922), available at http://www.ilo.org/ilolex/cgi-lex/convde.pl?R019 (last visited on Sept. 2, 2010).

24 ILO, Inspection of Emigrants Convention (1926), available at http://www.ilo.org/ilolex/cgi-lex/convde.p l?C021 (last visited on Sept. 2, 2010).

25 ILO, Migration (Protection of Females at Sea) Recommendation (1926), available at http://www.ilo.org/ilolex/cgilex/convde.pl?R026 (last visited on Sept. 2, 2010).

26 ILO, Migration for Employment Recommendation (1939), available at http://www.ilo.org/ilolex/cgi-lex /convde.pl?R061 (last visited on Sept. 2, 2010).

27 ILO, Migration for Employment (Co-operation between States) Recommendation (1939), available at http://www.ilo.org/ ilolex/cgi-lex/convde.pl?R062 (last visited on Sept. 2, 2010).

28 ILO, Migration for Employment Convention (1939), available at http://www.ilo.org/ilolex/cgi-lex/convde.pl?C066 (last visited on Sept. 2, 2010). 
Convention No. 97 of 1949 ("C97"), otherwise known as Migration for Employment Convention. It came into full force on January 22, 1952, that is, one year after ratification by two Member-States.

C97 defined the term migrant for employment as "a person who migrates from one country to another with a view to being employed otherwise than on his account and includes any person regularly admitted as a migrant for employment." It, however, excluded from its coverage frontier workers, short-term entry of members of liberal professions and artists, and seamen. 29

C97 prohibited discrimination on account of nationality, race, religion or sex. It afforded to immigrants lawfully within its territory "treatment no less favorable than that which a Member-State applies to its own nationals" with respect to remuneration, hours of work, holidays with pay, restrictions on home work, minimum age for employment, training, women's work and the work of young persons, membership in trade unions and enjoyment of the benefits of collective bargaining, accommodation and subject to certain limitations, social security.

Compared to the 1939 Migration for Employment Convention ("C66"), the equality of treatment which C97 afforded to migrant workers is broader in scope. It included collective bargaining, accommodation and social security although subject to limitations

Finally, C97 assured the migrant worker not only the right to transfer part of his earnings and savings but also, exemption from customs duties for the importation of personal effects, tools and equipment.

\section{b. R86 (1949): Migration for Employment Recommendation (Revised)}

R86 instituted guidance on, among others, the organization of the free service intended to assist migrants and the types of assistance that should be provided, as well as the information that Members should make available to the ILO. It provided for the regulation of intermediaries engaged in the recruitment, introduction or placement of migrants for employment. 30 R86 expected Members to develop and utilize all possibilities of employment. To this end, the international distribution of manpower and in particular, the movement of manpower from countries which have a surplus of manpower to those countries that have a deficiency must be facilitated.

Consequently, R86 called for the facilitation of migration by measures which are meant to ensure for migrants for employment: food and clothing upon arrival, vocational training, transfer of earnings and savings and capital, in case of permanent migrations, as well as access to schools. 31 In appropriate cases, Members were called

29 C97 Migration for Employment Convention of 1949, art. 11.

30 ILO, Guide to International Labour Standards 203 (1 $1^{\text {st }}$ ed. 2003).

31 ILO, R86 Migration for Employment Recommendation (1949), Pt. III, 10. 
upon to supplement the Convention (Revised), 1949, and the preceding Paragraphs of the present Recommendation by bilateral agreement. For this purpose, the Annex to R86 contains a Model Agreement.

\section{C143 (1975): Migrant Workers (Supplementary Provisions) Convention}

More than a quarter of a century later, ILO adopted Convention No. 143 of 1975 which was intended to address Migrations in Abusive Conditions and promote the Equality of Opportunity and Treatment of Migrant Workers. C143 which came into force on December 9, 1978 with the ratification by two Member States, was meant to supplement the provisions of C97 considering inter alia, that "he Preamble of the Constitution of the International Labour Organisation assigns to it the task of protecting the interests of workers, when employed in countries other than their own'" and that "evidence of the existence of illicit and clandestine trafficking in labour calls for further standards specifically aimed at eliminating these abuses." [Emphasis added]

The first serious attempt by ILO to address the concerns of migrant workers in irregular situation, C143 explicitly stated that a migrant worker who resides legally in a country but who has lost his employment "must not be regarded as being in an irregular situation by the mere fact of loss of employment." Moreover, he must enjoy "equality of treatment with nationals" with respect to security of employment, alternative employment and retraining. Furthermore, a migrant worker in an irregular situation and whose position cannot be regularized must enjoy equality of treatment for himself and his family with respect to past employment as regards remuneration, social security and other benefits.

C143 thus devoted Part I to Migrations in Abusive Conditions, Article 1 of which required in rather categorical terms each Member to which C143 is in force, "to respect the basic human rights of migrant workers." 32 The Member is likewise obliged to adopt all necessary and appropriate measures to suppress clandestine movements of migrants for employment and illegal employment of migrants and organisers of such movements in order to prevent and eliminate abuses 33 as well as to prosecute and penalize the author of manpower trafficking. 34

While meant to be supplementary to C97, C143 broadened the excluded group of migrant workers. In addition to the exclusion provided in Article 11.2 of C97, Article 11.2 of C143 excluded from its application, persons coming specifically for training or education and employees of organisations or undertakings operating within the country

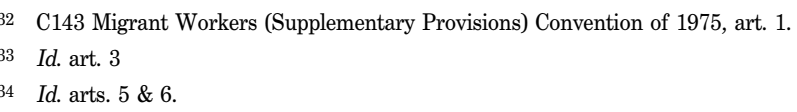


tasked with specific duties or assignments for a limited and defined period of time.

To date, despite the lapse of thirty-three (33) long years from its adoption, only twenty-three members have ratified C143.35 This leads credence to "the general impression that the international community has essentially ignored ILO instruments concerning migrant workers' protection." 36 Although the seeming indifference of the international community to ILO conventions pervades, these standards continue to provide the theoretical framework for the protection of migrant workers and their families.

\section{d. R151 (1975): Migrants Workers Recommendation}

R151 called upon Members to apply the provision of this Recommendation within the "framework of a coherent policy on international migration for employment" based upon the economic and social needs of both countries of origin and countries of employment." Account must be taken "not only of short-term manpower needs and resources but also of the long-term social and economic consequences of migration for migrants as well as for the concerned communities." 37

R151 assured migrant workers and members of their families lawfully within the territory of a Member enjoyment of an "effective equality of opportunity and treatment with nationals" with respect to access not only to vocational guidance and placement services but also access to vocational training and employment of their own choice as well as, provision of alternative employment, relief work and retraining. This equality of treatment extends to conditions of employment which include advancement, security of employment, remuneration for work of equal value, conditions of work, membership in trade unions, rights of full membership in any form of co-operative, and conditions of life including housing and the benefits of social services and educational and health facilities. 38

\section{Problems in Implementing ILO Conventions}

While C97 sets international standards specific to migrant workers' protection from entry to return, it affords protection only to those lawfully within the Members' territory. It took the ILO all of a quarter of a century to come forth with a Convention which provides protection to all migrant workers, irrespective of legal situation. Intended to eliminate abuses against migrant workers in irregular situation, C143

36 P. Daway, Filipino Migrant Workers' Rights and Status under International Law, 6 THE WorLd BuLL. (A publication of Univ. of the Phil. Law Center) 3 (2000).

37 Id. See also R151 Migrants Workers Recommendation of 1975, para. 1.

38 Supra note 36. 
categorically requires each Member to which C143 is in force, to respect the basic human rights of all migrant workers.

As regards C97, governments frequently cited Article 6 (equality of treatment between foreign workers and national workers) and Article 8 (maintenance of residence rights in the event of incapacity for work) as the provisions causing legal difficulties in application. In C143, three provisions cause the most difficulties: Article 8 (protection in the event of loss of employment), Article 10 (equality of opportunity and treatment) and Article 14(a) (Right of migrant workers to occupational mobility). ${ }^{39}$

A scholar opined that $\mathrm{C} 143$ which, as earlier mentioned, has only more than thirty adoptions despite the lapse of thirty plus years from its adoption, "seemed doomed from inception" and that "in part, the origins of the UN CMW (that is, the International Convention on the Protection of the Rights of All Migrant Workers and Members of Their Families) lay in the unacceptable nature of some provisions of ILO Convention 143." 40 (Words in parenthesis supplied) Citing another expert, R. Bohning, the scholar further stated that "developing countries preferred UN protection to the ILO because the organization was considered bound by Convention No. 143, and because it trusted the UN to protect its interests more than the ILO" adding that: "[P]art of the objection stemmed from a distrust of the ILO's tripartite structure and emphasis on independent trade unions" and that "most NGOs seem familiar with only the CMW." 41

Given that "the increasing reluctance on the part of States to enter into multilateral commitments in the area of policy on foreigners is a major factor" to non-ratification, an ILO Working Party (1996) concluded that "government intervention was not the best approach to managing the problems of labour migration." The scholar thus avers that this is "a telling commentary on the difficulty that ILO has in formulating governance strategies." In fact, it is "generally suggested that the UN Convention on Migrant Workers reflects the failure of ILO Convention No. 143 to engage the attention of the international community because it went too far." 42

Of course, ILO presents a better picture. In 1995, in a document submitted to the Sub-Committee on Prevention of Discrimination and Protection of Minorities, ILO claimed that "its activities had contributed substantially to acceptance of the concept of equality in the treatment of migrant workers and to the elimination of discrimination." It mentioned of "activities aimed at protection of migrant workers in Africa, America,

\footnotetext{
39 C143 Migrant Workers (Supplementary Provisions) Convention of 1975, available at http://www.ilo.org/ilolex/cgi-lex/ convde.pl?C143 (last visited on Sept. 2, 2010).

40 S. Kneebone, Governance of Labour Migration in South East Asia, The $6^{\text {th }}$ AsIAN L. Inst. Conf. (Hong Kong, May 29, 2009).

41 Id.

42 Id.
} 
Asia and the Pacific, and Europe through the application of international norms within the framework of the constitutional and national legislation of host States." 43

\section{B. Core International Human Rights Treaties}

The issue concerning the protection of the rights of migrant workers and members of their families cannot be overemphasized as all over the world they remain most vulnerable to abuse and exploitation. A UNESCO Report concerning migrant workers affirms the very rationale for the adoption of international human rights treaties. It avers that the "implementation of international human rights treaties is essential to ensure respect for the human rights of migrants." 44

These treaties include: (a) the International Convention on the Elimination of All Forms of Racial Discrimination ("ICERD," 1965); (b) the International Covenant on Economic, Social and Cultural Rights ("ICESCR," 1966); (c) the International Covenant on Civil and Political Rights ("ICCPR," 1966); (d) the Convention on the Elimination of all Forms of Discrimination Against Women ("CEDAW," 1979); (e) the Convention Against Torture and other Cruel, Inhuman or Degrading Treatment or Punishment ("CAT," 1984); (f) the Convention on the Rights of the Child ("CRC," 1989); and (g) the Convention on the Rights of Persons with Disabilities ("CRPD," 2006).

The foregoing treaties, in tandem with the International Convention on the Protection of the Rights of All Migrant Workers and Members of their Families ("ICMW") have been referred to as the "core international human rights treaties." The report emphasizes that: "[A]ll of them contain strong non-discriminatory clauses ensuring applicability of many provisions to migrants." 45

\section{The International Convention on Migrant Workers ("ICMW")}

At its 69th plenary meeting which was held on December 18, 1990, the United Nations General Assembly adopted, without a vote, the International Convention on the Protection of the Rights of All Migrant Workers and Members of their Families. Just over two months thereafter, on February 25, 1991 the General Assembly signed Resolution 45/128, adopting and opening for signature, ratification and accession the ICMW and expressed the hope that it will enter into force at an early date.

U.N. the Office of the High Commissioner for Human Rights ( "OHCHR”), UN Fact Sheets: No. 24 The Rights of Migrant Workers, available at http://www.humanrights.is/the-human-rights-poject/humanrightscasesandmaterials/ generalcomments/unfactsheets/No.24rightsofmigrantworkers (last visited on Sept. 2, 2010).

44 December 18, The UN Treaty Monitoring Bodies and Migrant Workers: A 'Samizdat'-Updated July 20076 (2008).

45 Id. 
Writing about the ICMW, Cholewinski, a foremost author on migrant workers' rights observes that the ICMW is "the culmination of [an] evolutionary process which has seen the development of universal standards protecting the rights of non-nationals." 46 He explains that the "question which begs an answer is whether the ICMW is indeed the culmination of this 'evolutionary process,' or whether it falls short of affording adequate protection for migrant workers and their families.”

\section{ICMW Preamble}

The ICMW Preamble reaffirms the principles and standards embodied in international instruments concerning human rights in general and migrant workers in particular. Indeed, the standards earlier established in ILO Conventions provided the foundation and framework on migrant workers' and their families' protection. Underscoring the importance and extent of the migration phenomenon, involving as it does, millions of people and a large number of States in the international community, the ICMW Preamble brings to fore the situation of vulnerability in which migrant workers and their families frequently find themselves, owing, among other things, to their absence from their State of origin and to the difficulties they may encounter arising from their presence in the State of employment.

The ICMW rationale obviously stems from the recognition that the rights of migrant workers and members of their families have not been sufficiently recognized everywhere. 47

\section{Coverage: Documented and Non-Documented Migrant Workers}

The ICMW covers all migrant workers and members of their families without distinction of any kind, specifically, sex, color, language, religion or conviction, political or other opinion, national, ethnic or social origin, nationality, age, economic position, property, marital status, birth or other status. That the intention is to expand its application is quite evident in the definition of the term "members of the family." Thus, it refers to persons married to migrant workers or having with them a relationship that, according to applicable law, produces effects equivalent to marriage, as well as their dependent children and other dependent persons recognized as members of the family by applicable legislation or applicable bilateral or multilateral agreements between the States concerned. 48

\footnotetext{
46 R. Cholewinski, Migrant Workers in International Human Rights LaW: Their Protection in Counries of Employment 79 (1997).

47 Supra note 36.

48 The International Convention on Migrant Workers ("ICMW"), art. 4.
} 
Moreover, the ICMW applies during the entire migration process of both migrant workers and members of their families, beginning with the preparation for migration to departure and transit, including the entire period of stay and remunerated activity in the State of employment and even the return to the State of origin or of habitual residence. 49

An important feature of the ICMW is the protection it affords not only to documented, but also to non-documented migrant workers. As defined, migrant workers and members of their families are documented or in a regular situation if they are authorized to enter, to stay and to engage in a remunerated activity in the State of employment pursuant to the law of that State and to international agreements to which that State is a party; and they are non-documented or in irregular situation if they do not comply with the conditions above provided. 50

\section{Inclusions/Exclusions}

Under the ICMW, the term 'migrant worker' is a catch-all provision which refers to a person who is to be engaged, is engaged or has been engaged in a remunerated activity in a State of which he or she is not a national. 51 The term thus includes categories of migrant workers excluded in other conventions such as seasonal workers.

Intended to limit its protection to only the most vulnerable migrant workers, ICMW excludes from its coverage: employees of international organizations and persons sent or employed by a State outside its territory to perform official functions, persons sent or employed by a State or on its behalf outside its territory who participate in development programmes and other co-operation programmes, investors, refugees and stateless persons, students and trainees, and seafarers and workers on an offshore installation.

\section{Specific Rights of Migrant Workers under the ICMW}

The rights guaranteed to migrant workers under ICMW can be more systematically categorized into: employment rights, trade union rights, social security rights, right to health, right to housing, right to family unity/reunion, right to education, cultural rights, political rights, and residence rights. 52 Some significant rights are made applicable to all migrant workers and members of their families irrespective of documentation, that is, whether in a regular or in irregular situation. These are found in Part III (Articles 8-35) of the ICMW. 
There are rights found in Part IV (Articles 36-56) which are applicable only to documented migrant workers and members of their families or those who are in a regular situation. Some rights are applicable only to particular categories of migrant workers and members of their families such as seasonal workers and self-employed workers (Part V, Articles 57-63).

\section{a. Employment Rights}

- Right to Equal Treatment with Respect to Terms and Conditions of Employment.

Article 25.1 Part III of the ICMW, which applies to both regular and irregular migrant workers, guarantees treatment not less favorable than that which applies to nationals of the State of employment in respect of (a) remuneration, (b) other conditions of work which include overtime, hours of work, weekly rest, holidays with pay, safety, health, termination of the employment relationship and any other conditions of work which, according to national law and practice, are covered by this term and (c) other terms of employment namely, minimum age of employment, restriction on homework and any other matter which according to national law and practice, is considered a term of employment. It is significant to note that Article 25.2 declares as unlawful provisions in private contracts of employment in contravention of the principle of equality of treatment.

- Right to Freely Choose Employment

Article 52.1 (which is found in Part IV and hence granted only to those with legal status) guarantees to migrant workers the right to freely choose their remunerated activity. However, the same is subject to the right of the State of employment to limit categories of employment where necessary in the interest of the State as provided for by national legislation or in accordance with its legislation concerning recognition of occupational qualifications acquired outside its territory. Moreover, Article 52.3 allows State restrictions on the choice of employment of migrant workers whose permission to work is limited in time, such as the policy of granting priority to its nationals. As regards members of a migrant worker's family, Article 53.1 grants free choice of employment to anyone who has an authorization of residence or admission that is without limit of time or is automatically renewable under the same conditions in Article 52.

\section{b. Trade Union Rights}

The trade union rights of migrant workers and members of their family are guaranteed under Articles 26 and 40 which are found in Parts III and IV of ICMW, respectively. While Article 26, which applies to all migrant workers and their families, grants them 
the right: (a) to take part in meetings and activities of trade unions and of any other associations established in accordance with law, with a view to protecting their economic, social, cultural and other interests, (b) to join freely any trade union and any such association, and (c) to seek the aid and assistance of any trade union and of any such association, Article 40 which applies only to documented migrants workers and their families, grants them the right to form associations and trade unions in the State of employment for the promotion and protection of their economic, social, cultural and other interests.

\section{c. Social Security Rights}

The grant of social security rights under the ICMW is couched in rather general terms, much like ILO Convention No. 143. Under Article 27.1, migrant workers and members of their families are assured the right to enjoy the same treatment granted to nationals in so far as they fulfill the requirements provided for by the applicable legislation of that State and the applicable bilateral and multilateral treaties. Moreover, Article 27.2 obliges States Parties to examine the possibility of reimbursing interested persons the amount of contributions made by them with respect to that benefit on an equal basis with nationals similarly situated, where the national law does not grant the said right.

\section{d. Right to Health}

The ICMW, under Article 28 (Part III) guarantees to both documented and undocumented migrant workers and members of their families the right to equal treatment with nationals with respect to any emergency medical care that is urgently required for the preservation of their life or the avoidance of irreparable harm to their health. However, equality of treatment with nationals as regards access to social and health services without qualification is guaranteed only to documented migrant workers and members of their families.

\section{e. Right to Housing}

Under Article 43.1 (Part IV), documented migrant workers and members of their families are not only given the right to equal treatment with nationals of the State of employment with respect to access to housing, including social housing schemes, and protection against exploitation in respect of rents but likewise, States of employment cannot prevent an employer of migrant workers from establishing housing or social or cultural facilities for them. As regards their working and living conditions, these must be in keeping with the standards of fitness, safety, health and principles of human dignity (Article 70). The view has been advanced that although there is no express grant 
of the right to acquire private property, this may be deemed comprehended within the meaning of "access to housing." 53

\section{f. Right to Family Unity/Reunion}

The ICMW recognizes the importance of the family as the natural and fundamental unit of society which is necessarily entitled to protection and mandates States Parties to take appropriate measures to ensure the protection of the unity of the families of migrant workers (Article 44). Obliged to take measures that they deem appropriate and that fall within their competence, States Parties are called upon to facilitate the reunification of migrant workers with their spouses or persons who have with the migrant worker a relationship that, according to applicable law, produces effects equivalent to marriage, as well as with their minor dependent unmarried children (Article 44.2). States of employment are also encouraged, on humanitarian grounds, to favorably consider facilitating reunification of migrant workers with their family members (Article 44.3). However, consistent with national sovereignty concerns about uncontrolled immigration, Article 44 allows States Parties to limit and control the entry of families of migrant workers.

\section{g. Right to Education}

The ICMW (Article 43.1.b \& c) ensures to documented migrant workers equality with nationals in respect of access to vocational guidance and placement services, and access to vocational training and retraining facilities and institutions. As regards nondocumented migrant workers, Article 25 assures equal treatment with nationals in regard to "other conditions of work" in accordance with national law and practice, implying that if by national law, vocational guidance and training are required, even undocumented migrant workers may benefit therefrom.

The same access to vocational guidance and training institutions and services is available to family members of migrant workers under Article 45.1.b,54 subject to certain requirements. With respect to their children, they have the basic right of access to education on an equal basis with nationals under Article 30.55 Moreover, access to public pre-school shall not be refused by reason of irregular situation of either the parent or child. This may be difficult in practice due to dangers when they come into contact with public authorities. In Articles 43.1.a and 45.1.a, the ICMW guarantees to documented migrant workers and their children the right to access to educational institutions and services on an equal basis with nationals subject of course, to the institution's admission requirements. This certainly facilitates integration of the children 
of migrant workers into the local educational system.

\section{h. Cultural Rights}

The ICMW obliges States Parties to respect the cultural identity of migrant workers and members of their families, irrespective of documentation under Article 31.1, Part III and to allow them to maintain cultural links with their States of origin. Regular migrant workers and their families are granted access to, and participation in, cultural life on an equal basis with nationals under Articles 43.1.g and 45.1.d. Moreover, Article 67.2 encourages States Parties to cooperate, as may be appropriate, on terms agreed upon by those States with a view to promoting adequate economic conditions for their resettlement and to facilitating their durable social and cultural reintegration in the State of origin. More importantly, States of employment are encouraged, under Article 45.3, Part IV, to facilitate for the children of migrant workers the teaching of their mother tongue and culture while States of origin are encouraged to collaborate whenever appropriate.

\section{i. Political Rights}

Very specific political rights are enshrined in the ICMW for workers and their families. Articles 26 and 40 assure migrant workers and their families of the right to participate in trade union activities in the State of employment. The right to general political activity, however, is not within the ambit of such grant. As regards, documented migrant workers and family members, they have the right to participate in public affairs of their State of origin, and to vote and to be elected at elections in accordance with law, the exercise of which rights shall be facilitated by the concerned state. In accordance with national law, migrant workers and family members may be consulted or may participate in decisions concerning the life and administration of local communities under Article 42.2. They may also enjoy political rights in the State of employment, if granted by that State under Article 42.3.

\section{j. Residence Rights or Rights to Stay}

Obviously, the right of residence is necessarily intertwined with the migrant worker's employment. Accordingly, States of employment are obliged to issue to migrant workers in regular situation authorization of residence for at least the same period of time as their authorization to engage in remunerated activity, where separate authorizations to reside and to engage in employment are required by national law pursuant to Article 49.1 (Part IV). Where termination of employment is effected prior to the expiration of authorization or work permits, migrant workers shall not be regarded as being in an irregular situation nor shall they lose their authorization of residence by 
the mere fact of termination prior to expiration of work permits, except where the authorization of residence is expressly dependent upon the remunerated activity for which admitted (Article 49.2).

Corollarily to residence rights, the right to leave any State, even the State of origin is granted to all migrant workers and family members under Article 5 (Part III). Consistent with the other rights recognized in Part III of the ICMW, this right shall not be restricted except by law or when necessary to protect national security, public order, public health or morals or the right and freedom of others. More importantly, Article 21 (Part III) declares it unlawful to confiscate, destroy or even attempt to destroy identity documents, documents authorizing entry to or stay, residence or establishment in the national territory, work permits, or passports of migrant workers or members of their families to ensure, for example, their stay for the duration of their employment. Finally, under Article 22, all migrant workers and family members, that is, whether documented or not, are protected against arbitrary expulsion.

\section{Persisting Problems in the Implementation of ICMW}

A decade ago, the author wrote:

Even a cursory perusal of the list of ratifying and acceding states would reveal that there is hardly a major State of employment which is in the list. This shows that the States of employment are reluctant to embrace the ICMW in the main because of their reluctance to give up certain sovereignty rights, which will be inevitable once they accept the provisions of the ICMW which specify the rights and benefits that must be accorded to migrant workers and members of their families. Indeed, the prospect of ratification/accession by States of employment remains remote to date. 56

What was written above remains valid to date. While in theory, the ICMW affords full protection to the rights of migrant workers, the list of countries which have either ratified or acceded to this convention hardly shows any State of employment or receiving country. To illustrate, of the top ten destinations of Filipino migrant workers, namely: Saudi Arabia (28.3\%), United Arab Emirates (19.9\%), Qatar (8.7\%), Hong Kong (8.0\%), Singapore (4.3\%), Kuwait (4.0\%), Taiwan (4.0\%), Italy $(2.3 \%)$, Canada $(1.8 \%)$ and Bahrain (1.3\%), 57 none has signed or ratified the ICMW to date. 58

56 Supra note 36.

57 Philippine Overseas Employment Administration ("POEA"), Overseas Employment Statistics, available at http://www.poea.gov.ph/html/statistics.html (last visited on Nov. 12, 2009).

58 UN Treaties Collection, International Convention on the Protection of the Rights of All Migrant Workers and Members of their Families, available at http://treaties.un.org/Pages/ViewDetails.aspx?src=TREATY\&mtdsg_no=IV$13 \&$ chapter=4\&lang=en (last visited on Nov. 15, 2009). 
While the above-data would seem to validate the aforequoted statement, implying that States of employment remain as ever reluctant to embrace the ICMW and are apparently not amenable to the idea of extending full protection and providing ample benefits to migrant workers, there are receiving countries or States of Employment which provide the legal mechanisms by which to afford some measure of protection to migrant workers who, admittedly, have been contributing to their economic development.

\section{Impact of Migrant Labour on the Economies of States of Employment}

As adverted to in an earlier publication, "[T]he sheer magnitude of the number of migrant workers making the exodus from their States of origin makes it apparent that States of Employment, most of which are the affluent first world countries, have become increasingly dependent on labour supplied by the struggling third world countries like the Philippines." 59 Indeed, the significant contribution of migrant workers to the economies of States of employment cannot be ignored nor denied.

At the First Regional Conference on the Protection of Foreign Workers in Asia under the auspices of the Asian Society of Labour Law ("AsianSLL") which was held in Taiwan, 60 the papers presented by Labour Law academics and practitioners from participating States of employment or receiving countries, namely, China, Hong Kong, Japan, Malaysia, Mongolia, South Korea and Taiwan were one in stating that migrant workers have contributed significantly to the economies of countries which they represent.

Thus, the paper presenter from China categorically stated that the dramatic increase in the number of foreign workers "promote[d] the social and economic development of China" although "it also brought about many management issues." 61

The Hong Kong paper highlighted the positive results from importing foreign workers whether they belong to the professional and entrepreneurial classes, or manual or domestic workers. Thus, professional workers helped maintain "Hong Kong's

59 Supra note 36.

60 This AsianSLL Conference was co-sponsored by the Taiwan Labour Law Association in cooperation with the College of Law, National Taiwan University and the College of Law, National Taipei University on November 21-22, 2009 at the International Meeting Hall, National Taiwan University.

61 Jingyi Ye, Study of Legal Policies Concerning Migrant for Employment in China, presented at the Asian Society of Labour Law ("Asian SLL": the First Regional Conference on the Protection of Foreign Workers in Asia, Taiwan) (Nov. 21-22, 2009). 
vibrant economy and its position as a leading international financial centre" while migrant domestic workers "facilitate the increasing phenomenon of dual-earning facilities, freeing local men and women from daily domestic tasks including childrearing and care for elderly members of the family," not to mention that those admitted under the Supplementary Labour Scheme "facilitate construction of mega-projects, including the award-winning world class airport, and much of Hong Kong's internationally acclaimed sky-line." 62

Likewise, Japan has been importing foreign workers which the paper presenter attributed to labour shortage in the so-called '3K Labour.' It explained that $3 \mathrm{~K}$ stands for Kitanai or dirty, Kiken or dangerous, Kitsui or hard word and that the young people today do not want to work in $3 \mathrm{~K}$ workplaces. For instance, it is considered very hard work to take care of the elderly, the sick or handicapped persons. 63

Similarly, the influx of migrant workers was Malaysia's answer to labour shortage. As revealed in the paper presented by the President of the AsianSLL, to wit:

\begin{abstract}
Employing foreign workers from other countries has positive impact to the receiving country and vice versa. Foreign workers have earned reasonable amount of wages that have helped to support their families at home. Employers in the receiving countries have tremendously benefited from the presence of foreign workers as they have filled up the gap left by locals who considered jobs in certain sectors unconducive and unattractive. The Malaysian government is also the major beneficiary from foreign workers because the problem of severe labour shortage in the plantation sector has been substantially resolved. The same can be said to the construction industry and all these have enhanced and tremendously contributed towards the nation's economic growth. The impact of foreign workers in oil palm plantations can be seen in Sabah and Sarawak, states in East Malaysia which account for $40 \%$ of the whole Malaysian plantations. In 2008, Malaysia produced 17.73 million tones of palm oil worth RM65.02 billion in export values compared to the year 2007 which were RM45.17 billion. ${ }^{64}$ [Emphasis added]
\end{abstract}

The Mongolian paper cited the shortage of qualified workers in the industrial, mining and exploration sectors, among others, for importing workers. It cited the benefits derived from "skills and experiences of highly qualified foreign specialists." 65

While from the 1960s to the early 1980s, South Korea had been a labour sending country, in contrast and since the mid 1980s, the paper revealed that South Korea's

62 R. Glofcheski, The Status and Protection of Migrant Workers in Hong Kong, AsianSLL (Nov. 21-22, 2009).

63 K. Kagawa, Protection of Foreign Workers in Japan, AsianSLL (Nov. 21-22, 2009).

64 Nik Ahmad Kamal Nik Mahmod, Employment of Foreign Workers in Malaysia: Causes and Its Implication, AsianSLL (Nov. 21-22, 2009).

65 Bolormaa Soloon, The Current State of Sending Labor Force Abroad, AsianSLL (Nov. 21-22, 2009). 
rapid economic growth brought about serious labour shortage particularly in small and medium-sized manufacturing firms. Accordingly, the Employment Permit System ensures that foreign non-professional workers are employed only at small and medium enterprises and mainly in 3D (i.e., dirty, difficult and dangerous) industries. The system assures stable employment opportunities to Korean workers. 66

In Taiwan, the paper presenter noted that: "[F]oreign workers were allowed to enter and work for the first time in 1989 to meet the demand for labour on some government construction projects." Later, the sectors were expanded to include industrial workers, caregivers and housekeepers. Hence, for twenty years now, foreign workers have been the answer to Taiwan's labour shortage, helping promote economic development with their significant contributions in the fields of construction, manufacturing and domestic work. 67

The paper presented for Vietnam cites the shortage or "lack of high-grade technical workers" such as electricians and management experts for business involving new technologies, as the reason for importing foreign workers. While the significant contribution of foreign workers was acknowledged, stating that it led to a "more colorful' labour market, the paper categorically stated that Vietnam has no more need for unskilled workers. 68

\section{Migration Remains an Attractive Proposition}

Before the onset of the current global economic crisis, Secretary-General Ban Ki-Moon spoke of booming remittances which "stood as the most patent indicator of how migration contributes to development and to the well-being of families." He noted "a growing recognition of how the skills and know-how accumulated by migrants could be instrumental in transferring technology, capital, and institutional knowledge to their countries of origin." 69

On the part of sending States, it is not disputed that the major advantage of sending workers abroad is the inflow of remittances. In the Philippines, a country which sends one of the largest contingents of migrant workers to practically all parts of the globe on a daily basis, it was forecasted that migrant workers' remittances by the end of 2009 would amount to U.S.\$17.1 billion or a growth of $4 \%$ from 2008 despite global economic

\footnotetext{
John Lee, Employment Policy for Foreign Workers in South Korea, AsianSLL (Nov. 21-22, 2009).

Chin-Ching Cheng, Regulation and Protection of Foreign Workers in Taiwan, AsianSLL (Nov. 21-22, 2009).

68 Luu Binh Nhuong, Legal Issues on Foreign Workers in Vietnam and Vietnamese Overseas Workers, AsianSLL (Nov. 21-22, 2009).

69 Supra note 6.
} 
crisis.70 Quite convincingly, the view has been posited that: "[M]igration is not wholly a personal decision motivated by desire for capitalist accumulation, but also reflects the lack of development policies on the part of the government and the lack of satisfactory living and employment opportunities within the home country" and thus, the Philippine government has "deliberately promoted labour migration as a solution to unemployment and growing national accounts deficits." 71

While Vietnam may be considered as a Receiving State insofar as its foreign workers are concerned, the paper presenter at AsianSLL's First Regional Conference adverted to the 'great importance' of sending workers abroad to address the "problem of jobs and income." 72 Similarly, Mongolia, which may also be considered as a Receiving State, had to face migration of its citizens since its transition to a market economy at the beginning of the 1990s which brought about economic hardships in tandem with the significant increase in its population. 73

On the part of Asia's Giant, China refers to the dispatch of Migrant Workers abroad as overseas labour cooperation. Intended to promote employment opportunities, overseas labour cooperation has reportedly generated US $\$ 806$ billion to the concerned migrant workers. ${ }^{74}$

\section{Migrant Workers' Staying Power}

A Filipino academic who has done extensive research work on migration concludes that international migration is an offshoot of global capitalism, citing Massey thus:

As capitalism extends outward from core nations, and as Market relations penetrate countries in the developing and former communist world, noncapitalist patterns of social and economic organization are disrupted and transformed. $x x x$ large numbers of people are displaced from secure livelihoods as peasant farmers, family artisans, and employees of state-owned industries, creating a mobilized population prone to migrate, both internally and internationally. 75

70 P. Daway, The Legal Regime Governing the Export of Filipino Workers, AsianSLL (Nov. 21-22, 2009).

71 O. De Guzman, Overseas Filipino Workers, Labor Circulation in Southeast Asia, and the (Mis)management of Overseas Migration Programs, available at http://Kyotoreview.cseas.Kyoto-u.ac.jp/issue/issue3/article_281.html (last visited on Nov. 12, 2009).

72 Supra note 68.

73 Supra note 65.

74 Liu Cheng, A Study on Chinese Regulations on Migrant Workers Abroad, AsianSLL (Nov. 21-22, 2009).

75 ML, Alcid, An Overview on the Global Presence of Filipinos: Location, Discourse and Engagements, presented at U.P. Academic Congress (Feb. 1-5, 2010). 
She went on to quote the President of the Philippines who captures the essence of the diaspora in the following manner:

\begin{abstract}
These movements occur in all directions, not just south-to-north, but also south-tosouth, north-to-north, and in every other conceivable direction. It is this ceaseless and restless movement of people that truly links our respective countries, not just the capital or goods that economists love to build their growth models on. It is people who stimulate the trade, business and economic exchanges that keep the global economy moving along. ${ }^{76}$
\end{abstract}

Indeed, amidst the claims that during a world economic crisis, migrant workers are often the first to lose their jobs, 77 the movements of people all over the world in search of the proverbial greener pasture have remained unabated.

\title{
VI. Measures and Mechanisms that Address Migrant Workers' Vulnerable Conditions
}

The First Regional Conference of the Asian Society of Labour Law provided an avenue by which Labour Law academics and practitioners from across Asia once again brought to fore the conditions of abuse and vulnerability to which migrant workers, wherever situated, are exposed.

Their discussions reveal not only the recognition of the significant contributions of migrant workers to their respective economies but more so, the concern for their plight and the intention to afford them legal protection as can be seen from a survey of employment-related laws in these countries.

Thus, the Administrative Regulations of Employment of Foreigners in China was promulgated in 1996 to further regulate the employment of foreign workers in China compared with what was previously in force, the 1987 "Provisions of Foreign Employment." The 1996 Regulations provide specific rules governing, inter alia, the qualifications of foreigners seeking employment in China, as well as the procedure for the grant of employment license. However, considering the rapid economic changes that now confront China including the present "trend of low-quality employment rushing into China," there is a need to reexamine certain provisions of the present Regulations to make them "more operational and also, more in line with international

\footnotetext{
Id.

7 Supra note 19.
} 
practices." 78

The Basic Law of the Hong Kong Special Administrative Region which serves as its Constitution, ensures the continuation of the laws and treaties previously in force as well as basic human rights including equality before the law. Article 39 of the Basic Law specifically continues in force the International Covenant on Civil and Political Rights, the International Covenant on Economic, Social and Cultural Rights, and the conventions as previously applied to Hong Kong. There are other laws which regulate employment,79 foremost of which is the Employment Ordinance (Cap 57). This provides a floor of rights and protections to all workers, local and migrant.

However, as regards migrant domestic workers ("MDWs"), the protection of the Employment Ordinance may not be relevant because of the onerous Conditions of staff imposed on them by the Director of Immigration. For instance, MDWs are not permitted to change employers. Moreover, the law does not provide for maximum hours of work, leaving daily working hours unregulated for as long as fourteen (14) hours per day. .0

Labour laws apply to both the Japanese and foreigners under the Immigration Control and Refugees Recognition Act consistent with the "principle of equal treatment." Japan ratified the International Covenant on Economic, Social and Cultural Rights in 1975 and the International Convention on the Elimination of Racial Discrimination in 1995 to prevent discrimination on the basis of race, colour, sex, language, religion, political or other opinion, national or social origin, property, birth or other status although ILO Conventions on Immigrants (Nos. 66, 97 \& 143) have not been ratified. 81

The Japanese Constitution likewise protects the rights of all workers, Japanese or foreigners. Moreover, the Labour Standards Act and the Trade Unions Act both prohibit discrimination with respect to wages and working conditions and union membership, respectively, on account of nationality or race among others.

Moreover, foreign workers may file claims against their employer for any pecuniary and non-pecuniary losses under Article 415 or 709 of the Civil Code, in addition to the benefits due them under the Workers Labour Accidents Compensation Act. Finally, documented foreign workers may be insured under the employment Insurance Act of 1974.82

In Malaysia, the Employment Act of 1955 ("EA 1955”) grants unto foreign workers

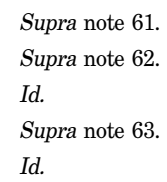


equal protection similar to local workers pursuant to Section 1 which defines the term 'employee' as including any person who has entered into a contract of service with an employer regardless of, among others, nationality. 83 Protection comes in the form of standard minimum terms and conditions of employment. Under the Industrial Relations Act 1967, a collective agreement given cognizance by the Industrial Court shall apply to 'all workmen' which has been interpreted by the Court to include 'foreign workmen.' Citing the Secretary-General of AsianSLL, Dr. Sharifah Suhanah, the AsianSLL President writes that: "[T]his decision represents a major breakthrough for migrant workers in Malaysia in their struggle to gain recognition for their contribution towards Malaysia's economic development through fair and equitable treatment." 84

While neither a member of the United Nations nor the ILO, Taiwan is an active member of the international community. Its constitutional court upholds the protection of human rights as a major national policy and recognizes foreign workers' human rights as an important issue. Consequently, national treatment is guaranteed to foreign workers who are thus entitled to the protection of all relevant laws including the Labour Standards Act ("LSA"), the first major labour legislation applicable to foreign workers whereby they are entitled to protection in the areas of wages, working hours and other conditions of work. 85 Also, foreign workers who are employed by companies which employ more than five workers enjoy labour insurance coverage like local workers. However, foreign housekeepers and caregivers are not normally employed by companies and hence, not covered by labour insurance. Moreover, foreign workers in Taiwan who are injured in a work-related accident are entitled to protection under the Protection for Workers Incurring Occupational Accidents Act ("PWIOAA”). 86

In South Korea, foreign workers are guaranteed the same basic rights and interests as Koreans under the Trade Union and the Labour Relations Adjustment Act, Industrial Safety Health Act and the Minimum Wages Act. ${ }^{87}$ However, because South Korea implements the Employment Permit System which ensures stable employment opportunities for Koreans by using foreign workers only as "supplementary and substitute," foreign workers are employed only at small and medium enterprises and mainly in three D (Dirty, Difficult, Dangerous) industries.88

As an ILO member since 1969 which has ratified 16 conventions and applicable

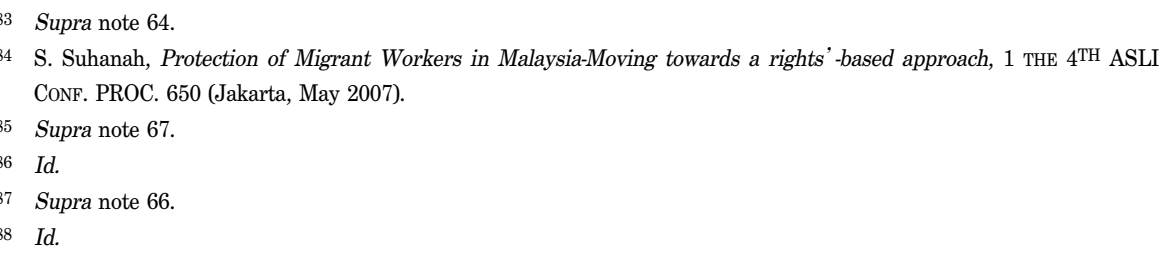


recommendations to date, Mongolia affords equal treatment to foreign workers under its national laws and upholds their rights and interests. 89

\section{The Need for an Integrated Comprehensive Regional Program in Asia}

More than ever today, it cannot be over-emphasized that migrant workers as human beings are possessed of rights. 90 As a professor of Philippine Constitutional Law aptly puts it, workers who migrate from their countries of origin in search of better lives for themselves and their families do so without leaving behind their fundamental rights and status as human beings; consequently, they retain their human dignity as human beings and continue to be entitled to the promotion and protection of their rights and status under general principles of international human rights law. 91

Viewed thus, the question that needs to be addressed continues to be whether or not the existing ILO Conventions and Recommendations as well as the core international human rights treaties together with the ICMW have been adequately implemented in order to effectively address the problems related to the promotion and protection of migrant workers' rights. Given the flood of unabated reports and complaints of abuses and exploitation that migrant workers the world over have to suffer and contend with, the answer is quite obvious.

ASEAN - the regional organization composed of Southeast Asian countries - has been exerting earnest efforts to address the need to protect and promote the rights of migrant workers. This is, of course, mete and proper considering that the region sends the biggest numbers of migrant workers to practically all countries in all the other continents of the world today.

In the words of the Convenor of the Task Force on ASEAN Migrant Workers, "[A]s ASEAN moves towards regional economic integration by 2015, the deficiencies of national government policies on labour migration are becoming increasingly clear. Left unresolved are many challenges to promoting a fair deal for migrants, protecting their rights (especially of undocumented workers), and developing strategies to put an end to trafficking of workers."

89 Supra note 65.

90 S. Samydorai, Acknowledgment, Civil Society Proposal: ASEAN Framework Instrument on the Protection of the Rights of Migrant Workers 10, Task Force on ASEAN Migrant Workers ("TF-MW") (2009).

91 C.V. Sison, Human Rights of Migrant Workers, presented at the Legal Forum-Kapisanan ng Migranting Pilipino, Inc. (2002). 
He thereupon made a call for a "comprehensive regional approach" for the purpose of building an "effective collaboration between labour sending and receiving countries." Moreover, he stressed "an urgent need to sketch out the rules and responsibilities of regional organizations like ASEAN towards migrant workers." 92

The ASEAN interest in the creation of an ASEAN Instrument or a regional agreement that will protect and promote the rights of migrant workers was heightened with the adoption of the Vientiane Action Programme ("VAP") at the 10th ASEAN Summit in Vientiane, Lao PDR on November 29, 2004.93 The ASEAN Security Community included as one of its strategic thrusts, political development which would involve, among others, the promotion of human rights and obligations. As part of the Programme Areas and Measures, an ASEAN instrument on the protection and promotion of the rights of migrant workers was to be elaborated. The VAP Call was reinforced by the 2007 ASEAN Declaration on the Protection and Promotion of the Rights of Migrant Workers which was adopted by the ASEAN Leaders on January 13, 2007 in Cebu. ${ }^{94}$

In response to the ASEAN Call, the Task Force on ASEAN Migrant Workers ("FTAMW") took the initiative to conduct "bottom up consultation processes to garner inputs from civil societies in ASEAN." Accordingly, eight National Consultations were held by ASEAN Member States - namely, Indonesia, Thailand, Philippines, Vietnam, Malaysia, Cambodia, Laos and Singapore - beginning 2007 until 2009, not to mention 7 regional consultations. ${ }^{95}$ After a two-year intensive consultation process, TF-AMW submitted to the ASEAN Secretariat civil society's "Framework Instrument on the Protection and Promotion of the Rights of Migrant Workers" on May 12, 2009 at the $6^{\text {th }}$ ASEAN Senior Officials Labour Meeting in Vientianne, Lao PDR.96

TF-AMW national and regional consultations ensured inputs from trade unions and civil society in order to have a meaningful participation of migrant workers and their representatives in formulating a comprehensive proposal. 97

The recently crafted ASEAN Instrument contains four (4) sections which are as follows: (1) Obligations of Labour Receiving Countries ("LRC"); (2) Obligations of Labour Sending Countries ("LSC"); (3) Joint Obligations of Labour Sending and Labour Receiving States; and (4) Commitments of ASEAN.

TF-MW, Civil Society Proposal, available at http://www.aseansec.org/VAP_10th\%20ASEAN\%20summit.pdf (last visited on Sept. 2, 2010).

93 Id.

94 Id.

95 Id. at 12.

96 Id.

97 Id. at 14. 
As regards the section on obligations of LRC, key recommendations include ensuring that migrant workers are treated in accordance with the core labour standards of the ILO.98 Among others, the Instrument calls for according 'national treatment' to migrant workers in terms of wages, hours of work, working conditions, worker benefits and welfare, as well as the use of standard contracts for hiring migrant workers throughout the region. The Instrument reaffirms the right of migrant workers to hold their original travel passport, work and personal documents and prohibits or penalizes the seizure of any such document. Moreover, the Instrument underscores the "special challenges facing foreign domestic workers and caregivers." Concerns related to mechanisms in changing employers, accommodations and living conditions, health service and occupational safety and health were addressed, including procedures related to marriage, birth registration, education of migrant worker's family and children, and access to legal systems and justice.

The heart and soul of the Instrument's first section is embraced in its "policy to abolish discrimination in all forms against migrant workers," to wit:

79. The ASEAN member Governments shall eliminate all forms of discriminatory policies and practices against migrant workers and ensure that all aspects of labour law, and social protection and anti-discrimination laws, are equally applied to all categories of migrants, in adherence with the principle of 'national treatment.'

80. Because migrant workers in ASEAN are increasingly female, the Member States of ASEAN shall set out clear gender-sensitive polices on migration, and ensure that Government practices towards migrants reflect these gender specific migration policies. These practices should aim to be empowering rather than restrictive of women's migration and mobility.

Under the second section, LSCs are obliged primarily "to ensure the right to development, including the provision of opportunities for decent work, for their citizens within their own countries.” The Instrument calls for an effective pre-departure training and systems for migrant workers, cooperation in vocational training and capacity building, as well as effective systems and regulations of their departure from and return to country of origin. Governments of Member States are to ensure monitoring and regulation of labour recruitment agencies and brokers, as well as the effective reintegration of returning migrants. The overseas Embassies' pro-active role in protecting migrant workers is underscored.

On the joint obligations of LSC and LRC (third section), the foremost 
recommendation is the harmonization of national labour laws with ILO core labour standards. Member States are called upon to ensure an effective regulation of private recruitment industry, emphasizing transparency, accountability and affordability of recruitment systems, and issuance of sanctions against abusive agents and brokers (individual and/or corporate) in both sending and receiving countries including the encouragement of bilateral government-to-government recruitment systems. Likewise, the creation and support for practical and effective grievance and complaint mechanisms and referral systems for migrants are recommended. Other concerns include the migration of skilled labour and the ASEAN Framework Agreement on Services, accreditation of skills and education of migrant workers, effective prevention and suppression of human trafficking, establishment and implementation of systems to identify trafficking victims, and provision of support for victims of human trafficking. Member States are, moreover, obliged to improve bilateral and regional cooperation systems to protect migrant workers rights and to support the creation of a remittance system and savings schemes for migrant workers.

Under the fourth section, the ASEAN itself is obliged to establish regional mechanisms which will complement national efforts for the protection of migrant workers. Among such mechanisms are an electronically networked ASEAN Migrant Worker's ID that could supplement national passport, an ASEAN Hotline to provide information/advice or emergency assistance, portable insurance, and an ASEAN Migrant Fund. Moreover, Member States are to agree on an effective three-step process to receive and address grievances made by migrant workers or civil society organizations on behalf of an individual or group of migrant workers, including mediation and resolution.

\section{Conclusion}

Consistent with the stance of the International Organization for Migration which calls for the formulation of "flexible, coherent and comprehensive migration policies," ASEAN's urgent call is for the development of a "comprehensive regional approach."

There is a need for a continent-wide forum in Asia which can eventually consolidate all mechanisms and measures in order to promote and protect the rights of migrant workers in a truly comprehensive and integrated approach. In point is the Asia Cooperation Dialogue ("ACD"), the first of its kind in Asia with 30 member countries, which was inaugurated in June 2002 in Cha-Am Thailand with 18 Asian Foreign 
Ministers meeting together for the first time. Providing a venue "where Asian countries could freely discuss issues of common interest and put forward measures to enhance mutual cooperation in all areas," annual dialogues have been held to consider issues of regional cooperation and ways to enhance and solidify Asian unity. Considering that migration is an issue of transcendental concern among Asian countries whether as receiving or sending States, it is suggested that the ACD include migration as one of the areas of cooperation for purposes of developing "common approaches to positive issues." 99

At the 2004 ILO Conference on Migration, the ILO called for a "[f]air deal for all migrant workers based on a Rights-based approach in accordance with ILO principles and International Labour Standards.” Among the notable International Standards which serve as framework for national law and policy on migrant workers' protection, C97, C143 and their accompanying recommendations, R86 and R151, "[c]all for cooperation among States and measures to facilitate and control migration movements." 100

The framework of ILO plan of action for migrant workers comprise international guidelines on best practices in key areas: promoting managed migration for employees including bilateral and multilateral agreements between host countries and countries of origin addressing aspects such as admissions procedures, social security, integration policy and return; licensing and supervision of recruitment and placement agencies in accordance with ILO C181 and R188 with provision of clear and enforceable contracts by those agencies; promoting decent work for migrants; preventing abusive practices, migrant smuggling and trafficking in persons; protecting and promoting human resources of all migrants; preventing and combating irregular labour migration; and improving labour inspection and creation of channels for migrant workers to lodge complaints and seek remedy without intimidation. 101

The importance of a continuing global forum or conversation on international migration and development cannot be ignored nor downplayed. Indeed, the launching of the Global Forum on Migration and Development was forthcoming as an offshoot of the High-Level Dialogue conducted by the United Nations General Assembly in 2006. Consequently, at the First Global Forum on Migration and Development in Belgium the following year, 156 countries exchanged experiences and ideas on "leveraging remittances, fostering co-development, promoting the entrepreneurial spirit of

\footnotetext{
99 ASIA Cooperation Dialogue ("ACD”), available at http://www.acddialogue.com/about/index.php (last visited on Sept. 2, 2010).

100 Migrant NewSLETTER, Sept. 2004, available at http://www.december18.net/web/docpapers/doc2072.doc (last visited Sept. 2, 2010).

101 Id.
} 
migrants, and helping countries of origin tap the skills of their migrants abroad." At the Second Global Forum in Manila in 2008, even more countries (that is, 163) discussed protecting the rights of migrants, fostering opportunities for regular migration and improving policy coherence through partnerships. 102

Ban Ki-Moon notes that: "[R]elationships among policymakers across the world are being reinforced daily, laying the groundwork for more cooperative efforts between countries of origin and countries of destination." The Global Forum is aimed at fostering "cooperation so that we can draw the most from human mobility" with the end in view of creating the so-called " $[t]$ riple win' for countries of origin, for countries of destination, and for the migrants themselves." 103 After all, it is basically a symbiotic relationship that exists between the receiving countries or States of Employment and the migrant workers together with their States of Origin. It is akin to a partnership where both parties are obliged to contribute their share for the good and profit of their partnership which in turn, is expected to redound to the benefit of all the parties and not just one of them.104 Then and only then, can we ensure that migration will be an effective tool for development and progress of humanity. 